the conduct of public affairs on modern lines-yet when the searchlight of anthropological investigation is turned on to indirect rule as a working system, difficulties in giving it full effect and shortcomings in its practice begin to appear. In the earlier days of British administration in Africa, it was assumed, perhaps too readily and without intensive anthropological inquiry, that each local unit must be subordinated to a headman or chief, and ruled by him with or without a council of elders. In either event, it was assumed to be a system susceptible of individual representation. In default of a more penetrating examination, it was not realized that local sovereignty, to use an expressive, if not a fully applicable, term, was bound up with religious ritual, belief and organization, upon which the native was not only reticent, but also incapable of expounding the ramifications except in response to the patient inquiry of an experienced and trained observer. Hence the system of native courts composed of members, who have come to be called "warrant chiefs', was by no means invariably in accord with native institutions, while the legitimate representative of native authority, according to tradition, was often relegated to the background, either through native reticence or the influence of a more forceful personality.

THE relation of the warrant chiefs to the real seat of native authority has been carefully analysed by Prof. C. Daryll Forde, who, as a Rockefeller Research Fellow of the International Institute of African Languages and Cultures, has made a special study from this point of view of the tribal customs of the large village centre of Umor in the Obubra Division of Southern Nigeria, with a population of more than 10,000 (Africa, 12, 2 ; 1939). Not only does he show how intricate an affair is native traditional machinery for the preservation of order and for local administration, but he also goes on to show how native custom and principles in local administration have been controverted by the appointments made, in the praiseworthy desire to secure the representation of native knowledge and opinion. At the time of Prof. Forde's investigation in 1935, reform of the composition of the native court was under consideration, and the moral of his report is clearly that any change should be made only after intensive inquiry into the details and essential character of native institutions. $\mathrm{He}$ himself has certain constructive suggestions to make; but at the same time he points out that it is now difficult to make that use of native institutions which at one time was open to the Government. The interest of the natives has been diverted from their own institutions to the form which has been imposed upon them by the white man, and among them discussion has tended to centre on the methods of appointing warrant chiefs rather than on any radical reform, which would allow for the incorporation of the traditional system in the administrative machinery, or its development in that direction. Further, the young men have formed a group now actively in opposition to traditional authority in village affairs. It is evident that if native institutions are to be used and developed as a means to native education and civic training, some compromise will have to be effected. Otherwise native institutions and the stabilizing influence of tradition will go by the board.

\section{International Standard for Chorionic Gonadotrophin}

AT the third International Conference on the Standardisation of Hormones, held at Geneva on August 11-13, 1938, it was decided that international standards should be established for certain hormones of the anterior lobe of the pituitary gland and analogous substances found in urine and serum, and that international units should be defined in terms of a weight of each standard. The final preparation of these standards, their dispensing in a form suitable and convenient for the use of the laboratory worker, their storage, preservation and subsequent distribution, was to be undertaken by the National Institute for Medical Research, Hampstead, London. The preparation of the international standard for the gonadotrophic substance of human urine of pregnancy (chorionic gonadotrophin) has now been completed. It has been prepared from substantial amounts of material generously provided by six firms in different countries. The individual samples having been approved by the Conference, a mixture was made and the standard has been finally dispensed in the form of $10 \mathrm{mgm}$. tablets. The international unit has been defined as the specific gonadotrophic activity of $0.1 \mathrm{mgm}$. of the standard preparation, an amount of activity similar to that required, under the conditions used by many workers, to cause cornification of the vaginal epithelium of the immature rat. Each tablet contains approximately 100 international units. As in the case of the international standards for other hormones, drugs and vitamins, the new international standard is held, on behalf of the Health Organisation of the League of Nations, at the National Institute for Medical Research, Hampstead, London, from which it can be obtained by national control centres established in other countries; workers in Great Britain should apply to the Department of Biological Standards, National Institute for Medical Research, Hampstead, London, N.W.3.

\section{Preservation of the English Countryside}

Ir may be remembered that at the Cambridge meeting of the British Association, Dr. Vaughan Cornish described his efforts to preserve the natural scenic beauty of the cliff regions near Sidmouth by ensuring that considerable tracts of land in his possession should be restricted entirely to agricultural purposes. The Times of April 26 announces that Dr. Cornish has decided to extend these restrictions to cover (during his lifetime) the lands of Thorn Farm, near Salcombe Regis. This is a place of considerable historic interest as well as of natural beauty, which takes its name from an old "Holy Thorn" tree used as a landmark from Saxon times, and replaced with 
suitable ceremonial by another whenever it died. This decision has, also, its scientific aspect, on account of the proximity of the Norman Lockyer Observatory to Thorn Farm, where (but for the action of Dr. Cornish) it would have been possible to erect some six hundred houses under the local town planning scheme. It is well known that the work of Greenwich Observatory is badly hampered by smoke and glare from the surrounding district. The erection of six hundred houses in the vicinity of the Norman Lockyer Observatory might have been the first step towards a similar interference with the work of this observatory, and it is a matter of satisfaction that this annoyance has been at least postponed during the lifetime of Dr. Cornish.

\section{Earliest Man}

Mr. J. REID MoIr, with an admirable sense of propriety, took as the text of his Huxley Memorial Lecture for 1939 before the Imperial College of Science and Technology on May 4 certain questions posed by T. H. Huxley in his famous book "Man's Place in Nature". There Huxley asked : "Where, then, must we look for primeval man ? Was the oldest Homo sapiens Pliocene or Miocene, or yet more ancient ?" Readers of Mr. Reid Moir's lecture in its published form ("The Earliest Men". By J. Reid Moir. London : Macmillan and Co., Ltd. Pp. 32. 1s. net) will appreciate the choice as lecturer on this occasion of an investigator of man's origins, who through his association with Edwin Ray Lankester is directly linked with Huxley, and also by his own researches has contributed so much of the material which must be taken into account by everyone who ponders the problems thus formulated by Huxley so long ago. The evidence of man's skeletal remains, as well as of his artefacts, which has been laboriously collected, pieced together and interpreted by numerous investigators since Huxley's day, ably summarized and surveyed by Mr. Reid Moir, may seem formidable enough in its detailed mass, but it is still far from offering a final solution of man's origins. Nevertheless it makes it possible to adumbrate a generalized formula, from which it may be that a concrete answer eventually will emorge. If in the meantime Mr. Reid Moir's technological and æsthetic arguments may seem a little overweighted in the period and degree of man's development they demand, and his credence in Miocene man a thought too readily conceded, none can deny that in his life work he has abundantly shown faith in that of which his powers of observation and reason have convinced him-the belief in the power of truth ultimately to prevail, which Huxley urged upon the youth of his time.

\section{Verulamium Museum}

The new Verulamium Museum at St. Albans, which has been erected by the Corporation at a cost of $£ 8,000$, was declared open by the Earl of Harewood on May 8. The purpose of the Museum is to house the finds from the excavation by Dr. R. E. Mortimer Wheeler and the late Mrs. Wheeler between 1930 and 1934 of the Roman city of Verulamium and the pre-
Roman Belgic city in Prae Wood. A tablet in the entrance hall commemorates Mrs. Wheeler's part in the excavation. The museum building, of which $\mathrm{Mr}$. F. Newton is the architect, and Mr. Philip Corder will act as curator, contains in addition to offices and laboratories, a museum hall $75 \mathrm{ft}$. long, in which are displayed a selection of the finest and most typical specimens from the two sites, grouped in an arrangement which will most readily convey their significance to the visitor. The large mass of material still under examination at the Institute of Archæology in London will eventually be stored in the Verulamium Museum, and though not displayed, will be available for students' reference. Three of the finest of the mosaic pavements discovered at Verulamium, including the square pavement displaying the remarkable head of a sea god, and the striking semi-circular scallop-pattern pavement of about A.D. 130-150, are shown on the end-wall, facing the visitor on entering. On the left of the entrance are the wall-cases containing the Belgic pottery, both imported and home-made, from the pre-Roman site of Prae Wood, ranging in date from about A.D. 10-40. The remaining cases are given up to exhibits from Verulamium. The material culture of the inhabitants of the Roman site is exhibited in the long series of burial groups, among which not the least interesting relic is a denarius of Augustus, which was converted into a Mithraic token some two centuries after its issue. A large model of the important south-eastern, or London, gate is also shown.

\section{Preservation of Fauna and Flora}

IN an address entitled "The Dawn of a Geological Period" delivered at the London School of Hygiene and Tropical Medicine on May 4 for the University of London, under an arrangement for an exchange of lectures with the Universities of Belgium, Prof. V. van Straelen, director of the Royal Natural History Museum of Brussels, discussed the inroads made on the fauna of the world by the activities of man and especially by the exploitation of Central Africa. He pointed out the fact, which is usually entirely neglected if not always unrealized, that not only are the larger mammals threatened with extinction by the advance of settled areas in tropical Colonies, but also that the felling of rain forests, by exposing the soil to the direct attack of sunlight, renders it impossible to reafforest such lands, and by completely altering all the micro climatic conditions, necessarily causes the destruction of all smaller plants and animals, whether they live above, upon or in the soil. In the light of his own great experience of such conditions, and of others the ultimate effects of which are similar, Prof. van Straelen showed that the changes of fauna and flora which are now occurring are in magnitude analogous to those which characterize the geological periods, and thus justified his title.

\section{Cosmic Rays}

Prof. P. M. S. BlacketT took "Cosmic Rays" as the subject of the thirtieth Kelvin Lecture which he delivered before the Institution of Electrical En- 